\title{
Popularisation of Knowledge on International Accomplishments of Special Education in the "Szkoła Specjalna" Magazine During the Inter-War Period
}

\begin{abstract}
:
The paper presents articles published in the "Szkoła Specjalna" ("Special School") magazine between 1924 and 1939, devoted to the accomplishments of special education in the world. In this period, knowledge about the modern foreign accomplishments in the area of education and care for people with disabilities was conducive to better organisation of the domestic system of special education and had fundamental significance for education and in-service training of special education teachers. In the analysed period, approx. 30 articles referring to foreign accomplishments in this discipline were published in "Szkoła Specjalna."
\end{abstract}

Keywords: special education, "Szkoła Specjalna” magazine.

The "Szkoła Specjalna" magazine celebrated its ninetieth anniversary in 2014. To honour this occasion, the paper of Anna Hryniewicka was published in the journal ${ }^{1}$, presenting its history, assumptions and purposes for which it was established, as well as the structure and problems tackled by individual divisions, along with authors of most interesting publications. Works mentioned by A. Hryniewicka include publications pertaining to the accomplishments of special education around the world. This issue seemed to have particular importance in the inter-war period, when Polish scientists, teachers, educational authorities and social activists faced the difficult tasks related to the reconstruction and extension of all levels of the educational system, development of science and research and establishment of new study majors, research areas and domains for the exchange of thoughts and experiences in the organised facilities. What is more, educational activities

${ }^{1}$ A. HRYNIEWICKA, Dziewięćdziesięciolecie czasopisma Szkoła Specjalna. Część I, Szkoła Specjalna, No. 1, 2015, pp. 5-15; A. HRYNIEWICKA, Dziewięćdziesięciolecie czasopisma Szkoła Specjalna. Część II, Szkoła Specjalna, No. 2, 2015, pp. 85-100. 
around the world also constituted an object of growing interest on the part of the Polish teachers and organisers of education.

This tendency also referred to the special education that emerged in the inter-war years. Knowledge about the modern foreign accomplishments in the area of education and care for people with disabilities in this period was conducive to better organisation of the domestic system of special education and had fundamental significance for education and in-service training of special education teachers. Conditions for creating scientific and practical foundations of this educational sub-discipline in Poland in the inter-war period were not favourable. Educational authorities, mainly due to the economic difficulties of the young independent state, did not focus attention on people with disabilities. However, thanks to the activities of Maria Grzegorzewska and her colleagues, institutional, organisational and scientific foundations of the Polish special education were developed in this period. The Special Education Institute, established in 1921, became the main centre bringing together specialists in this area. Maria Grzegorzewska put forward a proposal for publishing own magazine of the Institute, promoting issues related to the work with persons with disabilities. The "Szkoła Specjalna" ("Special School") magazine was a scientific and didactic quarterly and the first number appeared in 1924. In this very number Grzegorzewska published a text entitled "Zamiast programu" ("In Lieu of a Programme") detailing the nature of the magazine:

"Szkota Specjalna" is a publication of the Special Education Section and it serves its purposes and assumptions, contributing both to the development of teaching methods and education of children with disabilities, as well as self-improvement of teachers from special schools. "Szkota Specjalna" should be one of the basic areas for exchanging thoughts, procuring information about the scientific, organisational and methodological aspects of such education and intellectual approximation of colleagues dispersed around the entire country. All people working in this area should contribute their knowledge, experiences and observations supported by work results to the magazine for the general benefit. Do not shy away, do not look passively at such work, do not criticise it at the side, thus unproductively, but take active part in it with a kind thought and with faith in successful development, [...] so that everyone of us feels the coauthor of the magazine.

Apart from scientific, information and report type articles, "Szkoła Specjalna" will also publish reports from visits at schools, congresses, conventions, reports from the Polish and foreign work in the area of psychopathology, medical pedagogy and social care, as well as reports from domestic and foreign special education magazines ${ }^{2} . "$

Since 1924 to this day, "Szkoła Specjalna" has been a magazine with broad and wealthy content, devoted to the issues of special education and significantly contributing to the development of this scientific discipline. Since the very beginning, it has been one of the forms of operation of the Special Education Institute; academics and lecturers took active part in the establishment of the magazine. Selected presentations and lectures were often published in the magazine, along with academic accomplishments and experiences of individual divisions and employees of the Institute, which increased the magazine's

${ }^{2}$ M. GRZEGORZEWSKA, Zamiast programu, Szkoła Specjalna, No. 1, 1924, p. 3. 
value. Given the absence of textbooks and broader studies in the area of special education, which students of the Special Education Institute and teachers working in special education schools could use, the papers of academics published in "Szkoła Specjalna" were of great value ${ }^{3}$. In the inter-war period, the magazine presented content related to special education, which referred to the theory and practice of education and care for mentally disabled persons, persons with hearing and speech impairment, blind and sight-impaired persons, chronically ill persons, persons with mobility issues, as well as socially maladjusted persons. The periodical was also a platform for popularising knowledge in the area of auxiliary sciences, in particular psychology, psychopathology, sociology, neurology and others. The magazine featured articles in which the authors discussed the reforms of the special education system. This structure of the magazine made it forum for discussion about current problems in child care and became a valuable read not only for the special education teachers, but also for specialists from various scientific disciplines, interested in teaching, education, as well as social and professional adaptation of people with disabilities.

Significant attention was also devoted to the accomplishments of foreign centres in the area of theory and practice of special education. In the inter-war period, approx. 30 articles referring to foreign accomplishments in this discipline were published in "Szkoła Specjalna." It is worth emphasising that one issue of "Szkoła Specjalna" from 1929/30 was almost entirely devoted to the papers on special education in the world. Acquisition of knowledge in this area and use of foreign experiences was conductive to the support for special education teachers and educational activists in their work on the organisation of the Polish system of special education. In particular, it was due to the fact that the presentations pertaining to such education in other countries referred to fundamental issues, such as educational legislation, compulsory education, organisation of the system of special education, methods of teaching, curricula, didactic aids and training of personnel for the needs of such educational system. It should be stressed that the authors of publications visited the foreign facilities that they described, participated in classes and had insight into the maintained documents. Thus, these articles often put special emphasis on selected issues, interesting or significant for the author, and omitted others.

Among such publications several were devoted to the characteristics of the organisation of special educational system in various countries. "Szkoła Specjalna" published four of such articles written by Michał Wawrzynowski. The author presented the condition of the special education system in Austria $^{4}$, Czechoslovakia and Hungary, whereas issues pertaining to the training of special education teachers in Hungary are presented in a separate piece.

The author, portraying wealthy experiences and lengthy tradition of special education system in Hungary, noted that it was already in 1821 that the act on the obligation of

${ }^{3}$ L. FRYDRYCHOWSKA, J. GŁAZEM, Pięćdziesięciolecie Czasopisma “Szkoła Specjalna”, Szkoła Specjalna, No. 4. 1974, p. 291.

${ }^{4}$ M. WAWRZYNOWSKI, Szkolnictwo specjalne w Austrii, Szkoła Specjalna, vol. I, 1924/25, p. 205, 257; vol. II 1925/26, p. 14. 
sending morally neglected children to educational and reform centres was introduced, and in 1875 the act on legal non-liability of children with disabilities of "various categories." The new legal act, namely the Regulation of the Minister of Education of 1913, approved by the act of 1922, introduced compulsory education for mentally disabled children, hearing and speech impaired children, blind children, as well as the necessity of establishing and maintaining special education schools. In line with the document, compulsory education referred to children aged 7-15 or until the moment of completion of education at a given facility. Failure to fulfil the requirement of compulsory education resulted in a fine imposed on the parents in the amount of 500 crowns. Institutes of medical pedagogy were state, public (commune) and private with public rights, which were given by the Ministry of Education. The document specified that not more than 15 children could be taught in one class and one teacher was assigned to every class. Education in the special education centres lasted for eight years. A principle was adopted according to which if there were 70-100 children with disabilities in school age in the territory of a given district, education was organised by the district and the local authorities established the necessary facilities. Education in state facilities was free, and the costs were incurred by the state. Only persons who had proper preparation could work as teachers in such facilities and the training of teachers was the exclusive right of the state. The basis for acceptance to the teachers' training facility was a common school teacher diploma. The organisation, the curriculum and the teachers in such facilities were approved by the minister of education. The leading institution for training special education teachers was the Medical Pedagogy Training Centre. In a further part of the paper, M. Wawrzynowski presented thorough statistical data pertaining to the operating special facilities, their organisation, curricula and applied methods. He also offered quite a detailed description of individual facilities ${ }^{5}$.

In a similar manner, M. Wawrzynowski presented the situation of special education in Czechoslovakia. He stressed that in the discussed period, no central provisions functioned in the country which would regulate the issues of care and teaching of children with disabilities. However, he presented a description of operating facilities and paid special attention to the curricula and methods of teaching applied there. He also described the requirements pertaining to the teaching personnel. A person who had a common school diploma and who passed a special examination could work as a special education teacher. Wawrzynowski considered the fact of introduction, as of 1923, in all teachers' training centres, of twenty mandatory hours of lectures from special education very interesting and important $t^{6}$. Another interesting solution pertaining to the preparation of the teaching personnel for the needs of special education system was presented in materials pertaining to Hungary. The Academy of Medical Pedagogy, which started to operate in Budapest as of the beginning of school year 1926/ 1927 and which offered two-year courses, was transformed, pursuant to a decision of the Minister of Religious Denominations

${ }_{5}^{5}$ M. WAWRZYNOWSKI, Szkolnictwo specjalne na Węgrzech, Szkoła Specjalna, vol. I, 1924/25, pp. 120-136.

${ }^{6}$ M. WAWRZYNOWSKI, Szkolnictwo specjalne w Czechosłowacji, Szkoła Specjalna, vol. II, 1925/26, pp. $163-170$. 
and Enlightenment, into a university offering three-year courses. It adopted the name of Higher School of Medical Pedagogy. In his publication, the author presented excerpts from the school's organisational charter. Wawrzynowski considered it interesting that people not older than 30 were accepted for the studies, with diplomas of common schools, department and middle schools. Furthermore, he showed the organisation of the school with a detailed curriculum for every semester and a description of final examinations ${ }^{7}$.

The issues of hearing and speech impaired persons around the world were discussed in three publications in "Szkoła Specjalna." Marian Radwański presented the organisation of one of the oldest facilities of this type in an article entitled "Instytut dla głuchoniemych w Wiedniu" ("The Deaf-Mute Institute in Vienna"). In the article, the author discussed the issues of general care and education for the deaf-mute, which were prepared in detail and approved by the Austrian Ministry of Education. He emphasised the fact that children as young as 4 years of age were subject to the schooling obligation. He also drew attention to good organisation of kindergartens, where a lot of emphasis was put on the child's development in this period, which was testified by well-documented child observation sheets ${ }^{8}$.

In another publication entitled "Organizacja wychowania dzieci głuchych w Londynie" ("Organisation of Education for Deaf Children in London"), Jan Hellmann presented valuable remarks on the system of education for the deaf-mute in the London County. The author noted that in spite of the fact that deaf-mute children started their education at the age of seven, activities were undertaken to establish facilities and kindergartens where work with children as young as three years of age could be started. Hellmann remarked that in 1922, education was offered to 560 deaf and dumb children and 116 partially deaf and dumb children, which constituted, $87.2 \%$ and $85.7 \%$ of children registered in schools 9 . On the other hand, Eugeniusz Faliński in his work "Poradnie ortofoniczne w Paryżu" ("Orthophonic Clinics in Paris") indicated the significance of orthophonic exercises, which occupy a very important position in the work on correct pronunciation of hearing and speech impaired children, stimulating development of speech and also solidifying correct pronunciation. He presented in detail the pedagogical therapy methods as exemplified by such Parisian institutions as the Institute for the Hearing and Speech Impaired, Phonetic Institute, Herd Hospital, Leopold Bellan Hospital and Vaugirard Hospital. He noted that medical wards operated by doctors and pedagogical wards under orthophonic supervision operated in all of these facilities ${ }^{10}$.

"Szkoła Specjalna" also published articles devoted to foreign experiences in the work with blind children. Four articles were devoted to this subject matter. In her publication entitled "Szkoła dla ociemniałych w Zemuniu" ("School for the Blind in Zemun"), Felicja

${ }^{7}$ M. WAWRZYNOWSKI, Organizacja kształcenia nauczycieli szkół specjalnych na Węgrzech, Szkoła Specjalna, vol. III, 1926/27, pp. 180-183.

${ }^{8}$ M. RADWAŃSKI, Instytut dla głuchoniemych $w$ Wiedniu, Szkoła Specjalna, vol. II, 1929/30, pp. 163-100 .

9 J. HELlMANN, Organizacja wychowania dzieci głuchych $w$ Londynie, Szkoła Specjalna, vol. I, 1924/25, pp. 37-38.

${ }^{10}$ E. FALIŃSKI, Poradnie ortofoniczne w Paryżu, Szkoła Specjalna, vol. XII, 1935/36, pp. 170-178. 
Łuniewska presented a brief description of the school, paying attention to good vocational preparation of students and the fact that after graduation, the students received tools for work and a subsidy that allowed them to set up their own work place ${ }^{11}$. The headmaster of the school was V.W. Ramadanowitch, who published an interesting text in "Szkoła Specjalna", presenting the institution that he managed. In a work entitled "Kształcenie niewidomych w Jugosławii" ("Teaching of the Blind in Yugoslavia"), the author presented the history of care and education for the blind in Yugoslavia, as well as organisation of this system in the contemporary times. Nevertheless, most attention was devoted to the teaching personnel, the preparation and the principles of hiring in the facility. The teachers for the Institute were selected via a competition; the competition was open for candidates who had at least two years of practice in common schools. In this group, priority was given to the candidates who could speak one foreign language. After half a year of work at the Institute, the best teachers were selected who, after subsequent two years of practice, had to pass a special teacher's examination. A certified teacher for the blind had a right to a $10 \%$ increase of wages and received free accommodation at the Institute along with fuel for heating. Religion classes were also conducted by specialists and priests also had to pass a special examination. The exceptions were gymnastics and music teachers, as there were no specialists in these disciplines. A special feature was the fact that the teaching of music, handicraft, kindergarten education and teaching in the first two grades was entrusted to blind teachers. They had to have the same qualifications as fully able teachers; however, they were exempt from the practical examination. Having graduated, they completed a two-year practice at the Institute and passed a special examination for teachers. They had the same rights to remuneration as fully able teachers. In order to be entitled to full pension, they had to work for 35 years, similarly to fully able teachers. In a further part of the publication, the author described the functioning of the music school, implementation of the school curriculum, care for adult blind persons and the blind care associations operating in Belgrade. However, most attention was devoted to the Central Library located by the Institute. A printing house operated by the Library, which published books and notes; the number of copies ranged from 50 to 150. The task of the Library was to send books at own cost not only to other institutes, but also to all blind recipients. Additionally, the Library sent notes to former pupils of the facility, who were also music teachers. What is more, interested persons could receive a special daily newspaper for the blind, entitled "Braillowa Riznica", printed in Paris by American Braille Press. The editors also published and made available to the blind another journal of promotional nature, entitled "Glas Nedużnih" ("Voice of the Blind"), which discussed issues pertaining to the education of the blind, deaf and mentally disabled persons ${ }^{12}$.

The article penned by Jadwiga Brodzka entitled "Instytut dla niewidomych w Wiedniu i Pradze Czeskiej" ("Institutes for the Blind in Vienna and in Prague") describes the activities and the accomplishments of these institutions. The author emphasised extensive expe-

11 F. ŁUNIEWSKA, Szkoła dla ociemniałych w Zemuniu, Szkoła Specjalna, vol. I, 1924/25, p. 39.

12 V.W. RAMADANOWITCH, Kształcenie niewidomych w Jugosławii, Szkoła Specjalna, vol. VI, 1929/30, p. 112. 
riences of the institute in Vienna, which cared for and educated 1,202 children during the period of 125 years. The author considered performance of medical tests in the Institute important, along with reliable maintenance of medical records and diagnosing of the children's family situation. She emphasised that organisation of education for the blind was uniform, i.e. the same in all schools of this type, whereas the time of stay in the facility ranged from 11 to 15 years. The period of education lasted 8 years, whereas vocational training took 2-3 years. The facility offered good accommodation and the principles of coexistence of pupils were determined in the boarding house regulations. According to the author, a well-equipped library was also a great asset.

The second facility described by J. Brodzka was the Institute in Hradčany in Prague run by nuns. Schooling in this institution lasted for six years, a lot of attention was paid to music. The author particularly emphasised cooperation of the Institute with the adult labour centre organised by Alojzy Klara in 1832, where numerous workshops were located, allowing the students to gain professional skills ${ }^{13}$.

An interesting publication showing the work with hearing and sight impaired children is the paper of J. Bochnig, "Zakład wychowawczo-naukowy dla dzieci trzyzmysłowych w Nowawes" ("Educational Facility for Disabled Children in Nowawes"). The author described the operation of a complex of institutions operating near Berlin, including a clinic, a hospital, a children's home, a Froebel school, an economic seminary, a seminary for Froebel teachers, tailor and handicraft workshops, an orphanage for disabled children, a school for disabled children and primarily a facility for hearing and sight impaired children. The author detailed the organisation of the facility, the premises, the organisation of the day and the teaching programme, encompassing a transitional period, proper teaching and vocational training. Bochnig considered an attempt at diagnosing mentally disabled children a particularly valuable action. Taking into account the complexity of disabilities of children staying there, the task constituted a significant diagnostic challenge ${ }^{14}$.

A valuable initiative undertaken by the League of Nations for the sake of the sight impaired children was presented by Stanisław Posner in his article entitled "Dzieci niewidome w Lidze Narodów" ("Blind Children in the League of Nations"). The Advisory Commission for Child Care, operating by the League of Nations, representing eleven states and seven international organisations involved in child care, in 1926 submitted a motion for examining the condition of care for sight impaired children. As a result of the motion, the French side prepared a report on the situation of blind children in France. It presented information pertaining to the legal bases of special education in the country, statistics of sight impaired children, care and educational institutions for the blind, as well as associations supporting the blind. The presented report was a starting point for the commencement of systematic activities by the League of Nations with respect to care for children with disabilities. A resolution was adopted pursuant to which the Commission had the task

13 J. BRODZKA, Instytut dla niewidomych w Wiedniu i Pradze Czeskiej, Szkoła Specjalna, vol. VI, 1929/30, pp. 100-105.

14 J. BOCHNIG, Zakład wychowawczo-naukowy dla dzieci trzyzmysłowych w Nowawes, Szkoła Specjalna, vol. III, 1926/27, pp. 112-132. 
of collecting information about the situation of blind children in member states, statistical data and information about causes of disability ${ }^{15}$.

Issues related to re-socialisation and care for socially maladjusted and delinquent children and youth are presented in the works "Kurs postępowania z dziećmi trudnymi, nerwowymi i występnymi w Londynie" ("Course of Proceeding with Difficult, Nervous and Delinquent Children in London”)"16, "Opieka nad dziećmi i młodzieżą moralnie zaniedbaną w Austrii" ("Care for Morally Neglected Children and Youth in Austria"), "Sprawozdanie z wycieczki do Włoch" ("Report from the Trip to Italy") and a text of Wanda Szuman entitled "Wychowanie dzieci przestępczych w Belgii" ("Education of Delinquent Children in Belgium"). The author noted that in Belgium, a law was introduced in 1920 regulating, in a thorough and modern manner (according to Szuman), the issue of education of delinquent children. The issue was entrusted to the Ministry of Justice and the activities were aimed at putting an end to the prison-related system. In this period, two types of institutions were organised in Belgium, the first one for children below 14 years of age and older, less difficult, and for particularly difficult children, older than 14. The author described in detail the principles of operation of courts for juvenile delinquents and characterised the facilities functioning there, with special attention to their organisation, curricula and vocational training, as well as the principles of life in the facilities. The author considered attempts at separating children with other disorders, e.g. with mental disabilities, from the group of delinquent children, a valuable activity ${ }^{17}$.

On the other hand, Natalia Hanowa in a publication titled "Opieka nad dziećmi i młodzieżą moralnie zaniedbaną w Austrii" ("Care for Morally Neglected Children and Youth in Austria") emphasised that care for morally neglected youth in this country was closely related to the organisation of the system of education and legislation governing the operation of courts for juvenile delinquents and young offender institutions. These provisions encompassed seven facilities which operated there at that time. In performance of statutory provisions, attention was paid to the child's family situation in such a significant degree that reference was made to broadly understood care issues. Statutory provisions referred to children aged 14-18; children younger than 14 were not subject to courts but to care authorities. A special feature of the child care system to which the author paid attention were the so-called "meeting points" where all care problems were notified and where the child's situation was diagnosed and the case was referred to relevant institutions. It is important to note that minors who were held accountable were transferred under the care of court guardians, whose activities were closely related to the work of judges. In a further part of the publication, the author showed the organisation of the facilities that she visited, with special emphasis on the issues pertaining to education, in particular vocational train-

15 St. POSNER, Dzieci niewidome w Lidze Narodów, Szkoła Specjalna, vol. III, 1926/27, pp. 174-179.

${ }^{16}$ N. HANOWA, Kurs postępowania z dziećmi trudnymi, nerwowymi i występnymi w Londynie, Szkoła Specjalna, vol. VII, 1930/31, pp. 218-221.

17 W. SZUMAN, Wychowanie dzieci przestepczych w Belgii, Szkoła Specjalna, vol. II, 1925/26, pp. 220$-228$. 
ing, principles of establishing age groups, conditions of accommodation in the facilities, as well as preparation of the personnel ${ }^{18}$.

Natalia Hanowa presented similar remarks in a publication entitled "Sprawozdanie z wycieczki do Włoch" ("Report from a Trip to Italy"). She stressed that the system of care for morally neglected youth in Italy was meticulously prepared and was subject to the Ministry of Justice. It encompassed activities of associations and unions, the task of which was to care for mothers and children, as well as a network of facilities for socially maladjusted children and youth, along with courts for juvenile delinquents. Auxiliary institutions with respect to child care operated by the courts, detention centres and observation facilities. At that time, youth older than 14 was subject to penal liability in Italy. Minors below such age were put in reformatoria communae, where children were sent at the request of parents or municipal authorities. Placement of children in such a facility did not require a court decision. The second type of a facility were reformatoria giudiziare, intended for youth subject to court liability and sent there on the basis of a court decision. Particularly difficult youth was sent to a third type of facilities, namely the so-called casa di pena. In all types of facilities, the educational system relied on implementation of discipline and systematic work, whereas rules and regulations of the facilities were very detailed. Schools located by the facilities implemented the curriculum of common schools. Significant attention was also paid to the vocational preparation of pupils. The author attracted attention to the atmosphere in the facilities that she was able to visit. In her opinion, they were very sombre, quiet and monotonous; the pupils did not have any personal belongings. However, the facilities run by nuns (e.g. the Good Shepherd nuns) were quite different and the individual approach to children was clearly perceptible there ${ }^{19}$.

Accomplishments of foreign facilities with respect to work with mentally handicapped children are presented by three publications in "Szkoła Specjalna." It is necessary to mention the paper of A. Stefanowicz, "Organizacja zakładu dla upośledzonych umysłowo w Karolinie" ("Organisation of a Facility for Mentally Disabled Pupils in Carolina") 20, W. Szuman's article entitled "Umieszczanie dzieci anormalnych u obcych rodzin w Elsum (Belgia)" ("Placement of Disabled Children with Families in Elsum (Belgium)" and K. Dąbrowska's work "Organizacja wydzielania dzieci słabych umysłowo ze szkół powszechnych w Massachusetts" ("Organisation of Diagnosing Mentally Disabled Children in Common Schools in Massachusetts"). The paper of W. Szuman is particularly interesting; the author presents an experiment initiated in 1922 by Belgian authorities and consisting in placement of mentally disabled children with specially prepared families. The colony, consisting of several villages, was set up in Elsum, where 150 disabled children stayed with families of small farmers and craftsmen. These children also included children sent there pursuant to court decisions, thus morally neglected. A principle was also

${ }_{18}$ N. HANOWA, Opieka nad dziećmi i młodzieża moralnie zaniedbana w Austrii, Szkoła Specjalna, vol. VI, 1929/30, pp. 88-94.

19 N. HANOWA, Sprawozdanie z wycieczki do Włoch, Szkoła Specjalna, vol. X, 1933/34, pp. 165-168.

20 A. STEFANOWICZ, Organizacja zakładu dla upośledzonych umysłowo w Karolinie, Szkoła Specjalna, vol. VIII, 1931/32, knlb. 
adopted that children whose education in facilities did not offer the expected results would be sent to the Elsum families. Children staying with families were provided with medical and nurse care. They also attended a special school that was set up for them. Families were made liable for bringing up the children "as their own" and received a fee per child in the amount of three francs per day. If children worked, families were paid smaller amounts for the child's sustenance and the difference was credited to a savings account of a given child. The purpose of such initiative was best preparation of mentally disabled children for social life ${ }^{21}$.

On the other hand, the publication of K. Dąbrowska "Organisation of Diagnosing Mentally Disabled Children in Common Schools in Massachusetts" shows the organisation of care for the mentally disabled children. The initiative of early diagnosis and classification of mentally disabled children to special schools was proposed by Doctor Walter E. Fernald at the beginning of the $20^{\text {th }}$ century. Thanks to his cooperation with the Department of Mental Diseases and the Department of Education, operation of the so-call itinerant examination commissions was designated and legalised; their task was to diagnose children in schools. It was already in 1921 that such units were organised in 14 locations in the state, one for a specific area. The units operated by the state hospitals and state schools. The composition of a commission included specially trained personnel, which made use of an original method prepared for the purpose of the diagnosis. It is worth emphasising that between 1914, when the first such commission started to operate, until 1931, over 51,000 children were examined. According to the author, the American solutions could find their application in Poland, because in spite of the fact that preparation of special education teachers was on a high level, yet absence of close cooperation between school authorities and health authorities was clearly visible ${ }^{22}$.

"Szkoła Specjalna" also tackled issues related to care and bringing up of children with mobility problems. In a publication entitled "Opieka nad kalekami w Czechosłowacji" ("Care for the Disabled People in Czechoslovakia"), Michał Wawrzynowski stressed that in this country, care facilities were established in the first place and it was only in 1922 that a school was set up next to a care centre in Slavnice. Other institutions followed this example and, within a short period of time, subsequent facilities were set up in Prague (150 pupils) and in Brno (120 pupils). These facilities also accepted children with disabilities aged 5-18, who graduated only after they acquired a profession and were ready for independent life. In the facilities, special attention was paid to the classification of pupils with disabilities. According to statistics, the facility in Prague in the course of five years took care of 1,785 disabled pupils, including 1,295 who permanently resided in the facility and others who were covered by outpatient care. In the same period, 1,165 operations were performed in the facility, thanks to which patients regained ability. All facilities applied the same methods of treatment, therapy and also education. A school operated by every fa-

${ }_{21}$ W. SZUMAN, Umieszczanie dzieci anormalnych u obcych rodzin w Elsum (Belgia), Szkoła Specjalna, vol. III, 1926/27, pp. 112-112.

${ }^{22}$ K. DĄBROWSKA, Organizacja wydzielania dzieci słabych umysłowo ze szkót powszechnych w Massachusetts, Szkoła Specjalna, vol. X, 1933/34, pp. 169-172. 
cility. A rule was adopted in line with which every class could not have more than 12 pupils. The schools employed common school teachers. The author emphasised the principle adopted in the facilities in line with which in cases when disability of the pupil permitted it, he/ she was sent to an ordinary school. For pupils learning in the facility, frequent and long (10-day) scientific trips were organised. Children got prepared for the trips by becoming acquainted with history, geography and nature of the places that they visited. They acquired knowledge independently and the trips taught them principles of co-existence and contacts with the external world. The author of the article considered reliance of life in the facility on the self-government of pupils and excellently organised vocational training very interesting and valuable solutions. Vocational education in all facilities encompassed shoe-making, tailoring, basket-making, turning, wood-carving, weaving and gardening. Furthermore, the facility in Prague had an orthopaedic workshop; the facility in Brno a household workshop and the facility in Slavnice a household and farm work workshop. Pupils also received training with experts: photographers and book-binders ${ }^{23}$.

Extensive reports from congresses, conferences and scientific symposia were of great importance for the readers of "Szkoła Specjalna." Four of such reports were presented in "Szkoła Specjalna"; they described the course and the determinations made at the conferences in Vienna ${ }^{24}$, Munich ${ }^{25}$, New York ${ }^{26}$ and London. The reports were penned by Jan Hellmann and published in an article entitled "The $4^{\text {th }}$ International Congress on the Education of Hearing and Speech Impaired Persons." This was the sixth meeting of specialists in the area of education of the hearing and speech impaired, organised in London in 1925. Earlier congresses took place in Paris (1883), Milan (1880), Brussels (1880), Paris (1900) and Edinburgh (1907). Poland was represented for the first time. The congress was attended by delegates from Denmark, France, Germany, the Netherlands, Belgium, Sweden, Hungary, Italy, Spain, Czechoslovakia, Russia, Japan, China, Australia, India and Africa. In the course of the congress, the speakers referred to the most important issues, such as diagnosis and classification of the hearing and speech impaired pupils, methods of teaching, curricula and their improvement, vocational training for pupils, as well as training of special education teachers. The necessity of using state-of-the-art accomplishments from other areas of science, in particular psychology and medicine, in the improvement of education of the deaf and dumb was stressed. The presented papers were reliably prepared and contained a number of valuable information, as well as statistical data. One of the papers was devoted to the teaching of the deaf and dumb on a higher level. A college-level school was established in the United Stated by the facility for the hearing

${ }^{23}$ M. WAWRZYNOWSKI, Opieka nad kalekami w Czechosłowacji, Szkoła Specjalna, vol. VI, 1929/30, pp. 105-112.

${ }^{24}$ Wł. JARECKI, Sprawozdanie z I Kongresu lekarzy logopedystów w Wiedniu, Szkoła Specjalna, vol. I, $1924 / 25$, p. 40.

${ }_{25}$ F. KUHN, Sprawozdanie z II Kongresu Pedagogiki Leczniczej w Monachium, Szkoła Specjalna, vol. I, 1924/25, pp. 41-60.

${ }^{26}$ M. WAWRZYNOWSKI, Sprawozdanie z Kongresu w sprawie niewidomych w N. Jorku 13-30 kwietnia 1931, Szkoła Specjalna, vol. VII, 1930/31, p. 205; Szkoła Specjalna, vol. VIII, 1931/32, pp. 149-161. 
and speech impaired in Columbia at the end of the $19^{\text {th }}$ century. Education in the school lasted five years and the curriculum was very extensive. The first year was a preparatory year, and young people were accepted on the basis of an examination from history of America and England, calculations, algebra, physics and language grammar. In the subsequent years, students were taught English, French, Latin, algebra, geometry, history, including European history, political history of the United States, physics, chemistry, botany, zoology, physiology, astronomy, geology, political economy, logic, commercial law, sociology and citizenship. Specialist courses were also organised, devoted to agriculture, art, printing, higher mathematics, bacteriology, electro-technology and library studies, as well as household classes for girls. The school also organised higher-level courses, which allowed for acquiring the degree of the bachelor of arts and science and the master of arts and science. Approx. 130 students stayed in the facility, including 125 scholarship holders, to whom the Congress of the United States offered scholarships for talented and poor hearing and speech impaired students. The school also accepted girls who made up almost one-third of all students. The speakers emphasised that many graduates worked as teachers for the hearing and speech impaired and also continued studies at universities. In effect of the discussion, several motions were put forward. In one of them it was postulated that: "Every country should set up national committees, the purpose and the task of which would be extensive examination of the conditions pertaining to education, training, vocational and social preparation of the hearing and speech impaired persons. The results of such studies should be presented to a specially established international committee." On the other hand, the main motion of the London congress was a postulate to have the represented countries, via relevant legislation, exercise state care and control over the education of the hearing and speech impaired persons. It was also clearly emphasised that state authorities should pay the same attention to the children with disabilities and their education as to fully able children. The system of special education should form an integral part of the system of education and not adopt forms of charity activities ${ }^{27}$.

A very valued section of the presented magazine were "Reports and Reviews." In this section, reviews, often very detailed, of most recent scientific publications in the area of special education, were presented. Almost every issue of "Szkoła Specjalna" features several or even several dozen of such reviews. For example, issue No. 2 from 1929/30 included reviews of six foreign publications, whereas issue from 1933/1934 twelve. German, French and Russian publications were reviewed; what is more, serial publications were also presented and evaluated. The descriptions and the assessments of such publications were made by Natalia Hanowa, Jan Hellmann, Wanda Szuman and Felicja Łuniewska, thus persons with proper methodological background and extensive professional experience. Reviews included in the magazine were detailed and often very extensive. The readers had an opportunity of becoming acquainted in depth with the problems presented in the publication.

27 J. HELLMANN, VI Międzynarodowy Kongres Wychowania Gtuchoniemych, Szkoła Specjalna, vol. II, $1925 / 26$, pp. 14-42. 
A fixed element of "Szkoła Specjalna" was also the "International Chronicle" section. The chronicle was usually placed at the end of the magazine and presented information about various events from the country and abroad in the area of special education. There was regular information about congresses, symposia, scientific conferences, new magazines, exhibitions or technical innovations which improved the work with children with disabilities. Information was also provided, in the form of short notices, about current organisational, diagnostic, programme and methodological accomplishments in special facilities abroad.

It is worth adding that interest in the accomplishments of foreign facilities in the area of work with children with disabilities was so significant that teachers from Polish facilities often made attempts at becoming personally acquainted with their operation. It is exemplified by the experiences of teachers from the Lviv Facility for the Hearing and Speech Impaired. The minutes from the sessions of the pedagogical council feature information that Lviv teachers attended symposia and foreign conferences, as well as visited foreign facilities. For example, Rev. Władysław Szajda, representative of the Facility for the Hearing and Speech Impaired, participated in an international congress for the hearing and speech impaired persons in Leodium (Liege, Belgium), the purpose of which was to improve the situation of the deaf and dumb in the world. The congress was attended by 300 teachers and representatives of ministries of education from 21 countries. Papers presented by Polish scientists were particularly appreciated. He also visited foreign facilities and presented his experiences from these trips during several sessions of the pedagogical council, where he showed the reports from visiting foreign facilities for the deaf and dumb. In the first place, Szajda presented his remarks after visiting thirteen special education facilities in England, Belgium, the Netherlands and Germany (he visited two schools in London, three facilities in Belgium: two in Brussels and one in Berchem, four facilities in the Netherlands: two facilities in Michel Gestel and two in Amsterdam, four facilities in Germany: two in Berlin and one in Hamburg and Cologne). The next report was devoted to the facilities in Romania (Bucharest), Turkey (Smyrna), Greece (Athens), Yugoslavia (Belgrade) and Austria - two facilities in Vienna and three facilities in Hungary. The last report, entitled "O metodzie węgierskiej" ("The Hungarian Method") included a thorough analysis of a teaching method applied in Hungary, with which he became acquainted when visiting three facilities - two in Budapest and one in Kecskemet. In his reports, Szajda paid special attention to the organisation of the visited facilities, applied methods, didactic aids, but also the problems of the sector of the special education system.

Lviv teachers were also made familiar with foreign accomplishments in the area of teaching methods applied in America. Rev. Władysław Szanowski made the teachers of the Facility for the Hearing and Speech Impaired acquainted with the most recent accomplishments in special education by presenting a report entitled "Wrażenia z podróży do Stanów Zjednoczonych Ameryki Północnej" ("Impressions from the Trip to the United States of America"). He visited sixteen schools and facilities for the hearing and speech impaired and participated in an international congress in Chicago, where issues of new teaching methods for the deaf and dumb were discussed. He emphasised that a special feature of the educational system for the deaf and dumb in the United States was division 
of pupils into talented and less talented, speaking pupils, with traces of hearing and deaf. This made the work of teachers easier, along with selection of best methods for a given level of children ${ }^{28}$.

Publications devoted to the condition of the special education system in other countries presented in "Szkoła Specjalna" promoted valuable knowledge about various types of disabilities and state-of-the-art accomplishments in the area of education and care for persons with disabilities. The fact that so many papers devoted to special education in the world were published in the magazine suggests that there was significant interest in this issue and that these publications had great value for teachers and educational activists. Persons who were responsible for the organisation of education in the contemporary Poland might have been guided by certain solutions in the course of work on improvement of the educational law, creation of a school network and introduction of new solutions in this respect. For the teachers from special education schools and facilities, these publications, as well as reviews of scientific foreign publications, performed a skill-improvement role. Teachers and educational activists probably looked at their work more reflectively. The publications also performed a promoting role. By showing the importance attached by other countries to care and education for people with disabilities, they reinforced the attempts of Polish special education teachers to develop this discipline in Poland.

\section{Bibliography}

BOCHNIG J. 1926/27. Zaktad wychowawczo-naukowy dla dzieci trzyzmystowych w Nowawes, Szkoła Specjalna, vol. III, pp. 112-132.

BRODZKA J. 1929/30. Instytut dla niewidomych w Wiedniu i Pradze Czeskiej, Szkoła Specjalna, vol. VI, pp. 100-105.

DĄBROWSKA K. 1933/34. Organizacja wydzielania dzieci słabych umystowo ze szkót powszechnych w Massachusetts, Szkoła Specjalna, vol. X, pp. 169-172.

FALIŃSKI E. 1935/36. Poradnie ortofoniczne w Paryżu, Szkoła Specjalna, vol. XII, pp. 170-178.

FRYDRYCHOWSKA L., GŁAZEM J. 1974. Pięćdziesięciolecie Czasopisma "Szkoła Specjalna”, Szkoła Specjalna, No. 4, p. 291.

GRZEGORZEWSKA M. 1924. Zamiast programu, Szkoła Specjalna, No. 1, p. 3.

HANOWA N. 1929/30. Opieka nad dziećmi i młodzieża moralnie zaniedbana w Austrii, Szkoła Specjalna, vol. VI, pp. 88-94.

HANOWA N. 1930/31. Kurs postępowania z dziećmi trudnymi, nerwowymi $i$ występnymi w Londynie, Szkoła Specjalna, vol. VII, pp. 218-221.

HANOWA N. 1933/34. Sprawozdanie z wycieczki do Włoch, Szkoła Specjalna, vol. X, pp. 165$-168$.

HELLMANN J. 1924/25. Organizacja wychowania dzieci gtuchych w Londynie, Szkoła Specjalna, vol. I, pp. 37-38.

HELLMANN J. 1925/26. VI Międzynarodowy Kongres Wychowania Gtuchoniemych, Szkoła Specjalna, vol. II, p. 14.

${ }^{28}$ M. PĘKOWSKA, Nauczyciele lwowskich zakładów dla głuchoniemych i niewidomych wobec wymagań zawodu pedagoga specjalnego w latach 1918-1939, [in:] W stulecie śmierci Jana Władysława Dawida, ed. H. MARKIEWICZOWA, Wydawnictwo Akademii Pedagogiki Specjalnej, Warsaw 2014, pp. 192-193. 
JARECKI Wł. 1924/25. Sprawozdanie z I Kongresu lekarzy logopedystów w Wiedniu, Szkoła Specjalna, vol. I, p. 40.

KUHN F. 1924/25. Sprawozdanie z II Kongresu Pedagogiki Leczniczej w Monachium, Szkoła Specjalna, vol. I, pp. 41-60.

ŁUNIEWSKA F. 1924/25. Szkoła dla ociemniałych w Zemuniu, Szkoła Specjalna, vol. I, p. 39.

PĘKOWSKA M. 2014. Nauczyciele lwowskich zakładów dla głuchoniemych i niewidomych wobec wymagań zawodu pedagoga specjalnego w latach 1918-1939, [in:] W stulecie śmierci Jana Władysława Dawida, ed. MARKIEWICZOWA H., Wydawnictwo Akademii Pedagogiki Specjalnej, Warsaw 2014, pp. 192-193.

POSNER St. 1926.27. Dzieci niewidome w Lidze Narodów, Szkoła Specjalna, vol. III, pp. 174$-179$.

RADWAŃSKI M. 1929/30. Instytut dla gluchoniemych w Wiedniu, Szkoła Specjalna, vol. VI, pp. 95-100.

RAMADANOWITCH V.W. 1929/30. Kształcenie niewidomych w Jugosławii, Szkoła Specjalna, vol. VI, p. 112.

STEFANOWICZ A. 1931/32. Organizacja zakładu dla upośledzonych umystowo w Karolinie, Szkoła Specjalna, vol. VIII, no numbering.

SZUMAN W. 1925/26. Wychowanie dzieci przestepczych w Belgii, Szkoła Specjalna, vol. II, pp. 220-228.

SZUMAN W. 1926/27. Umieszczanie dzieci anormalnych u obcych rodzin w Elsum (Belgia), Szkoła Specjalna, vol. III, pp. 109-112.

WAWRZYNOWSKI M. 1926/27. Organizacja kształcenia nauczycieli szkół specjalnych na Wegrzech, Szkoła Specjalna, vol. III, pp. 180-183.

WAWRZYNOWSKI M. 1925/26. Szkolnictwo specjalne w Czechosłowacji, Szkoła Specjalna, vol. II, pp. 163-170.

WAWRZYNOWSKI M. 1924/25. Szkolnictwo specjalne w Austrii, Szkoła Specjalna, vol. I, 1924/25, p. 205, 257; vol. II 1925/26, p. 14.

WAWRZYNOWSKI M. 1929/30. Opieka nad kalekami w Czechostowacji, Szkoła Specjalna, vol. VI, p. 105.

WAWRZYNOWSKI M. 1930/31. Sprawozdanie z Kongresu $w$ sprawie niewidomych $w$ N. Jorku 13-30 kwietnia 1931, Szkoła Specjalna, vol. VII, p. 205; Szkoła Specjalna, vol. VIII, 1931/32, pp. 149-161.

WAWRZYNOWSKI M. 1924/25. Szkolnictwo specjalne na Węgrzech, Szkoła Specjalna, vol. I, pp. 120-136. 
